\title{
Erratum to: Classical swine fever virus NS5A protein changed inflammatory cytokine secretion in porcine alveolar macrophages by inhibiting the NF-KB signaling pathway

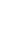

Xiao-Ying Dong ${ }^{1,2}$ and Sheng-Qiu Tang ${ }^{1,2^{*}}$

\section{Erratum}

Upon publication of this article [1], it was noticed that there had been an error in the processing of Fig. 4b. Although submitted correctly, the figure was published with the top left image missing. This has now been updated in the original article; please see the corrected figure below:

Received: 30 June 2016 Accepted: 30 June 2016

Published online: 03 August 2016

\section{Reference}

1. Dong XY, Tang SQ. Classical swine fever virus NS5A protein changed inflammatory cytokine secretion in porcine alveolar macrophages by inhibiting the NF-KB signaling pathway. Virol J. 2016;13:101.

\footnotetext{
* Correspondence: willertang@163.com

${ }^{1}$ College of Yingdong Agricultural Science and Engineering, Shaoguan University, Daxue Road, Zhenjiang District, Shaoguan 512005, China ${ }^{2}$ North Guangdong Collaborative Innovation and Development Center for Swine Farming and Disease Control, Shaoguan 512005, China
}

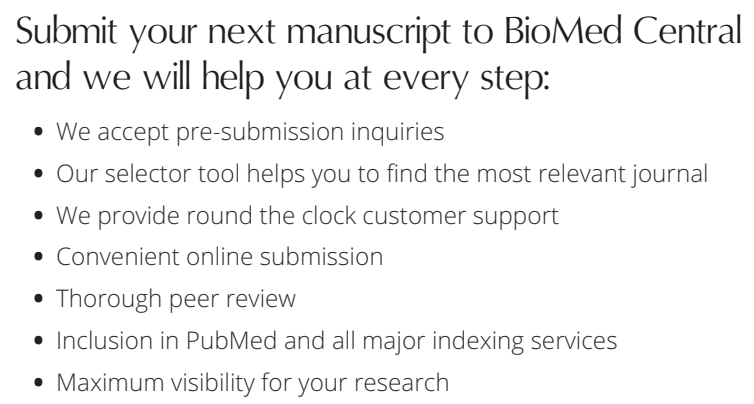

- We accept pre-submission inquiries

- Our selector tool helps you to find the most relevant journal

- We provide round the clock customer support

- Convenient online submission

- Thorough peer review

- Inclusion in PubMed and all major indexing services

- Maximum visibility for your research

Submit your manuscript at www.biomedcentral.com/submit \section{(1) CrossMark}




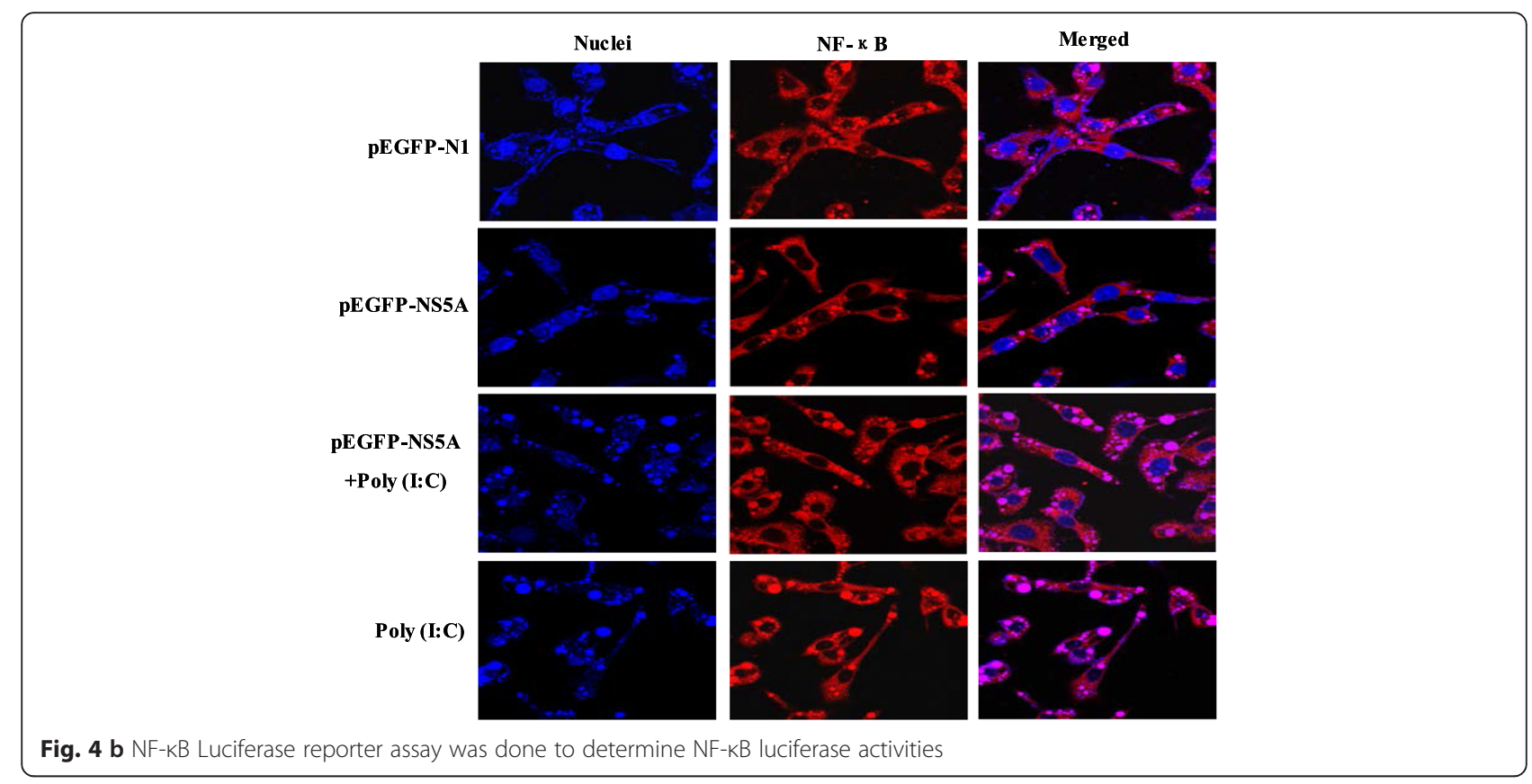

